\title{
Knowledge, attitudes and practices regarding HIV/AIDS among senior high school students in Sekondi-Takoradi metropolis, Ghana
}

\begin{tabular}{|c|c|}
\hline \multicolumn{2}{|c|}{$\begin{array}{l}\text { Authors: } \\
\text { Seraphine M. Dzah }{ }^{1} \\
\text { Elvis E. Tarkang } \\
\text { Prosper M. Lutala } \\
\text { Pro }\end{array}$} \\
\hline \multicolumn{2}{|c|}{$\begin{array}{l}\text { Affiliations: } \\
{ }^{1} \text { Department of Population } \\
\text { and Behavioural Sciences, } \\
\text { School of Public Health, } \\
\text { University of Health and } \\
\text { Allied Sciences, Ho, Ghana }\end{array}$} \\
\hline \multicolumn{2}{|c|}{$\begin{array}{l}{ }^{2} \text { HIV/AIDS Prevention } \\
\text { Research Network, Kumba, } \\
\text { Cameroon }\end{array}$} \\
\hline \multicolumn{2}{|c|}{$\begin{array}{l}{ }^{3} \text { School of Public Health and } \\
\text { Family Medicine, College of } \\
\text { Medicine, University of } \\
\text { Malawi, Blantyre, Malawi }\end{array}$} \\
\hline \multicolumn{2}{|c|}{$\begin{array}{l}\text { Corresponding author: } \\
\text { Elvis Tarkang, } \\
\text { ebeyang1@yahoo.com }\end{array}$} \\
\hline \multicolumn{2}{|c|}{$\begin{array}{l}\text { Dates: } \\
\text { Received: } 07 \text { July } 2018 \\
\text { Accepted: } 13 \text { Nov. } 2018 \\
\text { Published: } 09 \text { May } 2019\end{array}$} \\
\hline \multicolumn{2}{|c|}{$\begin{array}{l}\text { How to cite this article: } \\
\text { Dzah SM, Tarkang EE, Lutala } \\
\text { PM. Knowledge, attitudes } \\
\text { and practices regarding } \\
\text { HIV/AIDS among senior high } \\
\text { school students in Sekondi- } \\
\text { Takoradi metropolis, Ghana. } \\
\text { Afr J Prm Health Care Fam } \\
\text { Med. 2019; 11(1), a1875. } \\
\text { https://doi.org/10.4102/ } \\
\text { phcfm.v11i1.1875 }\end{array}$} \\
\hline \multicolumn{2}{|c|}{$\begin{array}{l}\text { Copyright: } \\
\text { (C) 2019. The Authors } \\
\text { Licensee: AOSIS. This } \\
\text { is licensed under the } \\
\text { Creative Commons } \\
\text { Attribution License. }\end{array}$} \\
\hline \multicolumn{2}{|l|}{ Read online: } \\
\hline 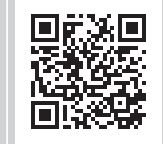 & $\begin{array}{l}\text { Scan this QR } \\
\text { code with your } \\
\text { smart phone or } \\
\text { mobile device } \\
\text { to read online. }\end{array}$ \\
\hline
\end{tabular}

Background: In Ghana, youths aged 15-24 years constitute the group most vulnerable to HIV infection. Inadequate knowledge, negative attitudes and risky practices are major hindrances to preventing the spread of HIV.

Aim: This study sought to investigate the knowledge, attitudes and practices regarding HIV/ AIDS among senior high school (SHS) students.

Setting: Sekondi-Takoradi metropolis, Ghana.

Methods: A descriptive, cross-sectional design was adopted, using a validated self-administered questionnaire, to collect data from a stratified sample of 294 senior students selected from three participating high schools in August 2017. The data collected were analysed using Stata version 12. Descriptive and inferential statistics were at a significance level of 0.05 .

Results: Among the participants, 61.6\% had good knowledge about HIV/AIDS, 172 (58.5\%) showed positive attitudes towards people living with HIV (PLHIV) and 79.1\% reported HIVrelated risky practices. We found a significant association between age and attitudes $(p<0.05)$. Poor knowledge was associated with being Muslim (aOR = 1.51 and 1.93; CI 1.19-1.91; $p=0.00$ ) and being a student from school ' $\mathrm{F}$ ' senior high school (F SHS) $(\mathrm{aOR}=1.93 ; \mathrm{CI} 1.71-2.18 ; p=0.00)$. Bad attitude towards PLHIV and HIV was associated with ages $15-19$ years (aOR $=3.20$ [2.58-3.96]; $p=0.03) p$ confirmed; and single marital status $(\mathrm{aOR}=1.79[1.44-2.23] ; p=0.00)$. Bad practices were associated with ages $15-19$ years $(\mathrm{aOR}=1.72[1.41-2.11] ; p=0.08)$, belonging to the Akans ethnic group $(\mathrm{aOR}=1.57[1.26-1.97] ; p=0.00)$ or being single $(\mathrm{aOR}=1.79[1.44-2.23] ; p=0.00)$. Associations between misconceptions and HIV transmission were found: HIV can be transmitted by a handshake $(\mathrm{aOR}=3.45[2.34-5.68] ; p=0.000)$, HIV can be cured $(\mathrm{aOR}=2.01[2.12-5.04] ; p=0.004)$ and HIV/ AIDS can be transmitted by witchcraft ( $\mathrm{aOR}=3.12[3.21-7.26] ; p=0.001)$.

Conclusion: Participants generally had inadequate knowledge regarding HIV/AIDS, manifested negative attitudes towards PLHIV and also engaged in risky practices that might predispose them to HIV transmission. Our findings underscore the need for culturally adapted and age-oriented basic HIV information for youths in the metropolis on misconceptions about HIV transmission, negative attitudes of students towards PLHIV as well as the risky practices of students regarding HIV.

Keywords: knowledge; attitudes and practice; HIV/AIDS; senior high school students; Sekondi-Takoradi, Ghana.

\section{Introduction}

Human immunodeficiency virus / acquired immunodeficiency syndrome (HIV / AIDS) has rapidly spread to many countries over the years since 1981 and is becoming a global health challenge.

Sub-Saharan Africa (SSA) is the worst affected region in the world, with about two-thirds of the afflicted people worldwide living here. ${ }^{2}$ According to UNICEF (2016) and UNAIDS (2018), the majority (about $80 \%$ ) of the 1.8 million adolescents living with HIV live in SSA..$^{2,3}$ Even in the general population, the majority (71\%) of the people living with HIV (PLHIV) as well as new HIV infections $(70 \%)$ and AIDS-related deaths (74\%) worldwide are recorded in SSA. ${ }^{4}$ Human immunodeficiency virus/acquired immunodeficiency syndrome (HIV / AIDS) has become the leading cause of death in Africa, and it is responsible for one in every five deaths in SSA. ${ }^{5}$

Ghana registered 250232 cases of PLHIV between 2006 and $2014 .{ }^{6}$ Of these, $92 \%$ were adults (15-49 years for women and 15-59 years for men) and 8\% were children (6-59 months). ${ }^{7}$ The adult 
HIV incidence is estimated at $0.07 \%$, with 11356 new infections and 9248 AIDS-related deaths recorded. The prevalence of HIV in Ghana is described as generalised over the years, with a prevalence rate of more than $1 \%$ in the general population. ${ }^{8}$ The HIV prevalence in the western region of Ghana stands at $2.5 \% .^{8}$ Although the prevalence rates of HIV/AIDS in Ghana are not as high as in other African countries, the disease still poses a challenge to the country's overall socio-economic development. ${ }^{9}$

Young adults, particularly those aged 15-24 years, are the group most vulnerable to HIV infection. ${ }^{10,11}$ This may be attributable to their engagement in risky life practices owing to lack of adequate information. ${ }^{12}$ Likewise, Ghanaians engage in their first sexual intercourse when they are in high school or of high school age. ${ }^{1}$ A study conducted in the Ashanti region of Ghana emphasised that most youth have pre-marital sex when young. ${ }^{13}$ Furthermore, youth present specific challenges that predispose them to HIV, some of them being lack of correct health information, lack of access to adequate reproductive health services, economic exploitation, changing lifestyles, global conflicts, ${ }^{14}$ exchange of sex to meet their needs and substance use. ${ }^{15}$

Knowledge, attitudes and practices (KAPs) regarding HIV/ AIDS serve as the cornerstones in the fight against HIV. Adequate knowledge regarding HIV/AIDS is a powerful way of promoting positive attitudes as well as engaging in safe practices. ${ }^{16}$ The attitude regarding HIV/AIDS in turn is expected to determine people's sexual behaviour. ${ }^{16}$ Many prevention programmes have focussed on increasing knowledge on transmission, with the aim of overcoming misconceptions that could prevent behavioural change towards safe practices and also reduce the stigma against PLHIV. $^{16}$

Several studies have been conducted in Africa and beyond to investigate KAP levels among students. These studies found that the knowledge of students regarding HIV was either average or poor, with misconceptions on high-risk practices among participants and a negative attitude towards PLHIV. Misconceptions were equally found in most KAP studies conducted among youths in different parts of Africa (Nigeria, Botswana, Gabon and other African countries) and beyond..$^{1,17}$

A study conducted in Nigeria to identify knowledge of HIV infection among secondary school students in Port Harcourt found that only $7.1 \%$ of participants listed the four modes of transmission, namely sexual intercourse, blood transfusion, mother to child (vertical) transmission and intravenous drug use. The above four modes of transmission were identified by only $31 \%, 14.4 \%, 9.1 \%$ and $8 \%$, respectively. Only $0.7 \%$ identified all the preventive measures. ${ }^{18}$ Another survey in western Nigeria assessing the level of awareness, knowledge and attitude towards HIV/AIDS among secondary school students in Atisbo Local Government Area, Nigeria, showed that participants possess relatively good knowledge of HIV/ AIDS, reasonable knowledge of safe sexual practices and positive attitude towards sexuality, HIV/AIDS and people living with PLHIV. ${ }^{5}$ But another study in Gabon which assessed HIV-related KAPs of high school and college students showed that students have inadequate information about HIV/AIDS transmission and prevention. Half of the respondents were aware of HIV transmission through sexual intercourse (55.7\%), from mother to child (48.3\%) and through sharing needles or syringes (51.8\%), and 25\% used condoms despite $15 \%$ being aware of unsafe practices with regard to HIV transmission. ${ }^{19}$

Misconceptions were also found in studies conducted in India $^{20}$ and Afghanistan ${ }^{21}$ where participants believed, for example, that HIV can be transmitted through toilet seats ${ }^{21}$ or mosquito bites. ${ }^{20,21}$ Negative attitude towards PLHIV was also reported by another study. ${ }^{20}$

Good knowledge of HIV does not always translate into good behaviour and/or safe practices. In Botswana, for example, a study conducted previously showed that half of the students could be perceived to be at risk of HIV, while the same participants thought that each sexually active student should be aware of his HIV status through regular testing. ${ }^{22}$

Youths need information to make responsible choices concerning their sexual behaviour. However, there is scarcity of studies addressing KAPs in HIV / AIDS among high school students in Ghana.

Although HIV/AIDS-related KAPs have been reported in studies from other countries and towns in Ghana, to our knowledge, there was no such information for students in Sekondi-Takoradi metropolis, Ghana.

The current study was therefore conducted to find out the KAPs regarding HIV / AIDS among senior high school (SHS) students in the Sekondi-Takoradi metropolis. This could serve as a guide to providing relevant information to health policymakers and other stakeholders in developing strategies related to supporting adolescents in improving their knowledge, attitudes, practices, values and skills needed to achieve the requisite behavioural changes to protect them from HIV infection in the Secondi-Takoradi metropolis of Ghana.

\section{Methods Study design}

A cross-sectional, descriptive study design was adopted with quantitative data collection methods. The choice of this study design was to obtain information which is a snapshot of a population at a certain time, allowing conclusions about phenomena to be drawn across a wide population. ${ }^{19}$

\section{Study site description}

Sekondi-Takoradi metropolis is located in the south-eastern part of the western region of Ghana. The metropolis is bordered to the west by Ahanta West District and to the east by Shama 
District. To the south of the metropolis is the Atlantic Ocean and to the north is the Wassa East District. It covers a land size of $191.7 \mathrm{~km}^{2}$, and Sekondi-Takoradi is the regional administrative capital. Although the smallest district in terms of land size, the Sekondi-Takoradi metropolis is the most urbanised among the 22 districts in the region. The population of Sekondi-Takoradi metropolis, according to the 2010 Population and Housing Census (PHC), was 559548 inhabitants, accounting for $23.5 \%$ of the region's total population. ${ }^{23}$

\section{Study population and sampling strategy}

The study population included students (both males and females) from three selected SHSs in the Sekondi-Takoradi metropolis - all boarding schools. This population was used because most of the participants (students) were aged between 15 and 24 years, which coincide with the age group most vulnerable to HIV / AIDS infection. ${ }^{12}$ All students who were in SHS and were present and consented to participate were included. The minimum sample size was obtained for this study by using the Cochran formula. ${ }^{24}$

$$
n=\frac{Z^{2} p q}{d^{2}}
$$

where,

$n=$ sample size,

$\mathrm{Z}=\mathrm{Z}_{\text {score }}$

$p=$ estimated proportion of an attribute that is present in the population,

$q=1-p$,

$d=$ margin of error.

It was based on the assumption of a margin of error of 0.03 , 95\% confidence level and an estimated proportion of HIV knowledge of Ghanaian youth (15-24 years) as $75.4 \%{ }^{25}$ and $0.03(3 \%)$ non-response rate.

$$
\begin{aligned}
\text { A sample size }(n) & =\frac{(1.92)^{2} \times 0.754 \times(1-0.754)}{(0.05)^{2}} \\
n & =285
\end{aligned}
$$

Adding a non-response rate of $3 \%, n=(285 * 0.03)+285=294$. Therefore, a total of 294 students who met the study inclusion criteria were recruited to this study.

A stratified sampling technique was employed in the study, where a proportional number of the students were drawn from each form (one and two) level. Calculation of the number of respondents in each grade level was based on the proportion of the population in the school register (sampling frame). That is, the study sample size divided by the total number in the school multiplied by the total number of students in each grade level. Then, using the sample size determined for each form, the number of respondents per form (grade level) was selected using simple random sampling. This was then computed to achieve the total sample size of 294.

\section{Data collection procedure}

A standard set of questionnaires was distributed among the students. Before administering the questionnaire, the nature of the study was explained to the students. They were assured of anonymity and confidentiality of their responses. The face and content validities of the instrument were ensured by comparing items with previous similar studies and by matching them with the stated objectives. In addition, a copy of the prepared questionnaire was made available to the project supervisor for vetting, review and careful scrutiny for the necessary amendments and corrections. Also, a pretest was carried out among 20 students in two schools that were not part of the study to ensure the reliability of the instrument. The principal investigator trained three data collectors about informed consent and the different sections of the questionnaires. The questionnaires were administered by the principal investigator and the three trained data collectors to all qualified students in the study. The questionnaires were administered during regular school hours. Students who volunteered to participate were made to sit apart and asked not to communicate with each other during the administration of the questionnaires so as to encourage honest responses, while the teacher was outside the classroom. After collecting the completed questionnaires, students were thanked for their participation in the study.

\section{Data analysis}

The data collected were entered into Epi Data Entry version 3.1 and exported to Stata version 12.0 for cleaning and analyses. Descriptive statistics such as frequencies, percentages, tables and charts were used to present the data. Logistic regression was also used to test associations between socio-demographic variables and KAPs of respondents regarding HIV / AIDS at the significance level of 0.05 .

\section{Ethical considerations}

Ethical approval for the study was sought from the Ghana Health Service Ethics Review Committee (GHS-ERC: 86/05/2017) with the help of the School of Public Health, University of Health and Allied Sciences, Ho, Ghana. Moreover, local permission and approval for the study was obtained from the headmasters of the various schools where the study was conducted.

\section{Results}

\section{Socio-demographic characteristics of the respondents}

The study comprised students aged 15-20 years. It was conducted in three schools in the Sekondi-Takoradi metropolis. (The letters S, F and T were used as pseudonyms for the schools to ensure anonymity.)

Table 1 shows that the majority of the respondents were females $(164 ; 55.8 \%)$ and aged between 15 and 17 years $(244 ; 83.0 \%)$. The mean age of the respondents was approximately 17.0 with a standard deviation of \pm 0.981 . Respondents were distributed almost equally across three different schools. Participants were mostly Christians (278; 94.6\%), and from the Fante ethnic group $(103 ; 35.0 \%)$. A vast majority of the respondents was single at the time of the 
TABLE 1: Demographic distribution of the respondents.

\begin{tabular}{|c|c|c|}
\hline Demography & Frequency $\dagger$ & Per cent \\
\hline \multicolumn{3}{|l|}{ Gender } \\
\hline Male & 164 & 55.8 \\
\hline Female & 130 & 44.2 \\
\hline \multicolumn{3}{|l|}{ Age group } \\
\hline $15-17$ years & 244 & 83.0 \\
\hline $18-20$ years & 50 & 17.0 \\
\hline \multicolumn{3}{|l|}{ Religion } \\
\hline Christian & 278 & 94.6 \\
\hline Islam & 15 & 5.1 \\
\hline African Indigenous & 1 & 0.3 \\
\hline \multicolumn{3}{|c|}{ Father's educational status } \\
\hline College & 78 & 26.5 \\
\hline University & 71 & 24.2 \\
\hline O-Level & 59 & 20.1 \\
\hline Senior High School & 43 & 14.6 \\
\hline Junior High School & 30 & 10.2 \\
\hline Primary & 13 & 4.4 \\
\hline \multicolumn{3}{|l|}{ Ethnic group } \\
\hline Fante & 103 & 35.0 \\
\hline Akan & 84 & 28.6 \\
\hline Ewe & 39 & 13.3 \\
\hline Ahanta & 28 & 9.5 \\
\hline Nzema & 28 & 9.5 \\
\hline Other & 12 & 4.1 \\
\hline \multicolumn{3}{|l|}{ Marital status } \\
\hline Single & 284 & 96.6 \\
\hline Dating & 9 & 3.1 \\
\hline Married & 1 & 0.3 \\
\hline \multicolumn{3}{|l|}{ Education/Grade level } \\
\hline Two & 200 & 68.0 \\
\hline One & 94 & 32.0 \\
\hline
\end{tabular}

Note: O-level is the abbreviation of ordinary level. It is one of the two parts of the genera certificate of education (GCE). It is the final certificate for secondary school, to be taken at fifth form or year 11 at approximately age 17.

$\dagger, n=294$.

study $(284 ; 96.6 \%)$, had fathers who went to college (71; $24.2 \%$ ), and had an education level of 2 years (200; 68\%).

\section{Knowledge of respondents regarding HIV/AIDS}

From Table 2, it can be seen that the majority of the respondents $(286 ; 97.3 \%)$ knew that HIV/AIDS can be transmitted via sexual intercourse, from mother to child (252; 85.7\%), through sharing needles or syringes (274; 93.2\%) and through blood transfusion (278; 94.6\%). Most respondents knew that HIV/AIDS cannot be transmitted through handshake $(239 ; 81.3 \%)$, by sharing clothes with an HIV-infected person $(205 ; 69.7 \%)$ and by mosquito bite $(206$; $70.1 \%)$. The majority of the respondents $(217 ; 73.8 \%)$ knew HIV/AIDS cannot be transmitted by witchcraft, while a slight majority $(178 ; 60.5 \%)$ knew it cannot be transmitted by using the same toilet seat as an HIV-positive patient. Notably, only a slight majority $(174 ; 59.2 \%)$ knew HIV / AIDS is not curable. The human immunodeficiency virus transmission is associated with the following misconceptions: HIV can be transmitted by handshake $(\mathrm{OR}=3.45 ; 95 \% \mathrm{CI}$ $2.34-5.68 ; p=0.000)$ and by witchcraft $(\mathrm{OR}=3.12 ; 95 \% \mathrm{CI}$ 3.21-7.26; $p=0.001)$. However, from Figure 1, it is clear that only a slight majority of the respondents had good knowledge regarding HIV / AIDS (61.6\%).
TABLE 2: Knowledge of respondents regarding HIV/AIDS.

\begin{tabular}{|c|c|c|c|c|}
\hline Variable & Frequency $\dagger$ & AOR & $95 \% \mathrm{Cl}$ & $p$ \\
\hline \multicolumn{5}{|c|}{$\begin{array}{l}\text { HIV can be transmitted by } \\
\text { sexual intercourse }\end{array}$} \\
\hline Yes & 286 & Ref. & - & - \\
\hline No & 5 & 1.2 & $1.94-4.07$ & 0.062 \\
\hline Do not know & 3 & 1.3 & $0.45-3.12$ & 0.321 \\
\hline \multicolumn{5}{|c|}{$\begin{array}{l}\text { HIV can be transmitted from } \\
\text { mother to child }\end{array}$} \\
\hline Yes & 252 & Ref. & - & - \\
\hline No & 29 & 1.89 & $0.12-6.67$ & 0.435 \\
\hline Do not know & 13 & 0.78 & $0.21-2.87$ & 0.671 \\
\hline \multicolumn{5}{|c|}{$\begin{array}{l}\text { HIV can be transmitted by } \\
\text { sharing needle or syringe }\end{array}$} \\
\hline Yes & 274 & Ref. & - & - \\
\hline No & 15 & 1.89 & $0.043-1.976$ & 0.073 \\
\hline Do not know & 5 & 0.19 & $0.90-1.82$ & 0.831 \\
\hline \multicolumn{5}{|c|}{$\begin{array}{l}\text { HIV can be transmitted by } \\
\text { blood transfusion }\end{array}$} \\
\hline Yes & 278 & Ref. & - & - \\
\hline No & 9 & 0.13 & $0.09-4.54$ & 0.654 \\
\hline Do not know & 7 & 0.9 & $0.65-2.81$ & 0.328 \\
\hline \multicolumn{5}{|c|}{$\begin{array}{l}\text { HIV can be transmitted by } \\
\text { handshake }\end{array}$} \\
\hline Yes & 39 & 3.45 & $2.34-5.68$ & 0.000 \\
\hline No & 239 & Ref. & - & - \\
\hline Do not know & 16 & 2.05 & $0.38-1.97$ & 0.981 \\
\hline \multicolumn{5}{|c|}{$\begin{array}{l}\text { HIV can be transmitted by } \\
\text { wearing the clothes of an } \\
\text { HIV-positive person }\end{array}$} \\
\hline Yes & 50 & 1.23 & $0.94-2.13$ & 0.076 \\
\hline No & 205 & Ref. & - & - \\
\hline Do not know & 39 & 0.21 & $0.72-3.10$ & 0.234 \\
\hline \multicolumn{5}{|c|}{$\begin{array}{l}\text { HIV/AIDS can be transmitted } \\
\text { by mosquito bite }\end{array}$} \\
\hline Yes & 58 & 2.13 & $0.54-2.98$ & 0.561 \\
\hline No & 206 & Ref. & - & - \\
\hline Do not know & 30 & 0.31 & $0.98-2.10$ & 0.391 \\
\hline \multicolumn{5}{|c|}{ HIV/AIDS can be cured } \\
\hline Yes & 82 & 2.01 & $2.12-5.04$ & 0.004 \\
\hline No & 174 & Ref. & - & - \\
\hline Do not know & 38 & 0.56 & $0.81-2.09$ & 0.213 \\
\hline \multicolumn{5}{|c|}{$\begin{array}{l}\text { HIV/AIDS can be transmitted } \\
\text { by witchcraft }\end{array}$} \\
\hline Yes & 44 & 3.12 & $3.21-7.26$ & 0.001 \\
\hline No & 217 & Ref. & - & - \\
\hline Do not know & 33 & 0.98 & $0.17-1.30$ & 0.912 \\
\hline \multicolumn{5}{|c|}{$\begin{array}{l}\text { HIV/AIDS can be transmitted } \\
\text { by using the same toilet seat } \\
\text { as an HIV-positive person }\end{array}$} \\
\hline Yes & 69 & 1.42 & $0.16-1.19$ & 0.813 \\
\hline No & 178 & Ref. & - & - \\
\hline Do not know & 47 & 2.9 & $0.27-4.06$ & 0.67 \\
\hline
\end{tabular}

AOR, adjusted odds ratio; $\mathrm{Cl}$, confidence interval; Ref., reference class. $\dagger, n=294$.

\section{Attitudes of respondents regarding HIV/AIDS}

It could be noted from Table 3 that the majority of the respondents $(233 ; 79.2 \%)$ were willing to care for their HIVpositive relatives. However, 169 (57.5\%) said they would not eat from the same bowl used by the PLHIV. However, the majority of the respondents $(219 ; 74.5 \%)$ were willing to continue their friendship with their HIV-positive friends. On the contrary, most of them, $(201 ; 68.4 \%)$ said they would not buy items from shopkeepers with HIV/AIDS. Most of the respondents said that students $(228 ; 77.6 \%)$ and teachers $(224 ; 76.2 \%)$ who are 
HIV positive should be allowed to continue their studies and teaching, respectively. The majority $(223 ; 75.9 \%)$ said they had never refused to take care of HIV / AIDS patients.

\section{Excluded in the analysis}

From Table 5, it is clear that Muslims (OR = 1.6; CI 1.23-2.06; $p=0.00)$ on one side, and Fante (OR = 1.74; CI 1.36-2.22; $p=0.05)$ and Ewe (OR $=1.54 ; \mathrm{CI} 1.17-2.02 ; p=0.02)$ ethnic groups on the other side, were almost two times more likely to have poor HIV/AIDS knowledge than Christians and others ethnic groups.

On multivariate analysis (Table 5), the Muslims and students from F SHS were almost two $(\mathrm{aOR}=1.51$ and 1.93; CI 1.191.91 and $1.71-2.18 ; p=0.00$ each) times more likely to have poor knowledge, while the Ahantas were three times more likely to have poor knowledge compared to the Nzemas. All these associations were statistically significant after adjusting for covariants.

Generally, a slight majority of the respondents (58.5\%) had positive attitudes towards PLHIV (see Figure 2).

\section{Practices of respondents regarding HIV/AIDS}

Table 4 presents the results of the practices of respondents regarding HIV/AIDS. Most of the respondents (217; 73.8\%) said they had never had sex before. The majority $(41 ; 51.9 \%)$ of those who had experienced sex before did not use a

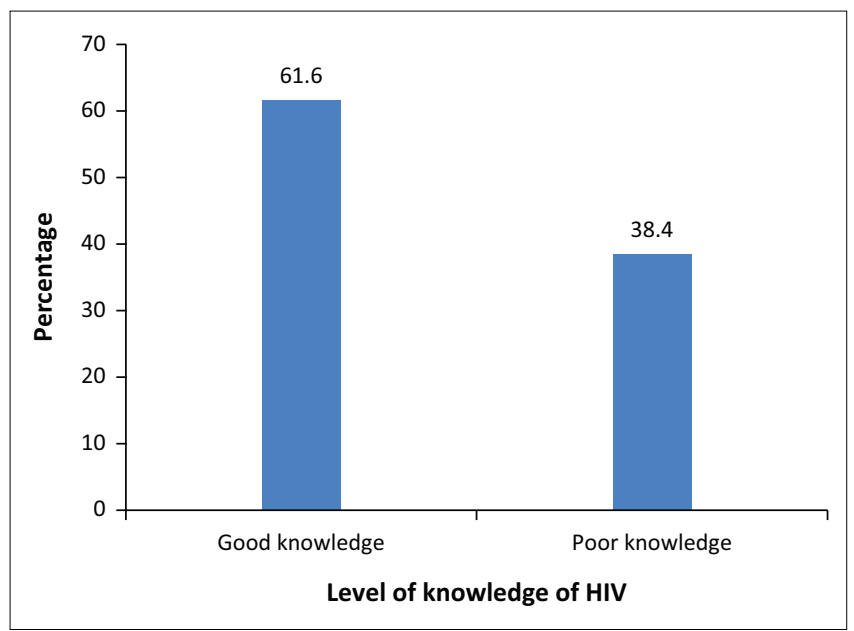

FIGURE 1: Level of knowledge of HIV/AIDS. condom during their first sexual encounter. However, the majority $(39 ; 50.6 \%)$ used a condom during their last sexual encounter. Only $32(41.5 \%)$ of the sexually active respondents always used a condom during sexual encounters. The findings also showed that more than half $(42 ; 54.5 \%)$ of the sexually active respondents had multiple sex partners in the year before this study. During the current study, the majority of the sexually active respondents $(49 ; 63.6 \%$ ) had a sex partner. The study findings indicated that the majority of the respondents $(262 ; 3.6 \%)$ was not using injection drugs. The majority $(14 ; 77.8 \%)$ of those who used injection drug equipment said they shared with other users. The majority of the respondents $(278 ; 94.6 \%)$ said they had never had an HIV test before.

TABLE 4: Practices of respondents regarding HIV/AIDS.

\begin{tabular}{llc}
\hline QABLE 4: Practices of respondents regarding HIV/AIDS. & & \\
\hline Question & Frequency & Per cent \\
\hline Had sex before? & 77 & 26.2 \\
$\quad$ Yes & 217 & 73.8 \\
$\quad$ No & 274 & 100.0 \\
$\quad$ Total & & \\
Used condom during first sexual & & \\
intercourse? ( $\boldsymbol{n}=\mathbf{7 7}$ ) & 37 & 48.1 \\
$\quad$ Yes & 40 & 51.9 \\
$\quad$ No & 77 & 100.0 \\
$\quad$ Total & & \\
Used condom during last sexual intercourse? & 39 & 50.6 \\
$\quad$ Yes & 38 & 49.4 \\
$\quad$ No & & \\
How regularly do you use condom during sexual \\
intercourse?
\end{tabular}

TABLE 3: Attitudes of respondents regarding HIV/AIDS.

\begin{tabular}{|c|c|c|c|c|c|c|}
\hline \multirow[t]{2}{*}{ Variable } & \multicolumn{2}{|c|}{ Yes } & \multicolumn{2}{|c|}{ No } & \multicolumn{2}{|c|}{ Do not know } \\
\hline & $N$ & $\%$ & $N$ & $\%$ & $N$ & $\%$ \\
\hline Would you be willing to care for your relative with HIV/AIDS? & 233 & 79.2 & 57 & 19.4 & 4 & 1.4 \\
\hline Would you eat from the same bowl used by a person living with HIV? & 124 & 42.2 & 169 & 57.5 & 1 & 0.3 \\
\hline Would you drink from the same cup used by a person living with HIV? & 81 & 27.6 & 212 & 72.1 & 1 & 0.3 \\
\hline If your friend is HIV-positive, would you continue your friendship with him/her? & 219 & 74.5 & 74 & 25.2 & 1 & 0.3 \\
\hline If a shopkeeper or food seller is HIV-positive, would you buy items from him/her? & 92 & 31.3 & 201 & 68.4 & 1 & 0.3 \\
\hline If a student is HIV-positive, should she/he be allowed to continue his/her studying in school? & 228 & 77.6 & 66 & 22.5 & 0 & - \\
\hline If a teacher is HIV-positive, should she/he be allowed to continue his/her teaching in school? & 224 & 76.2 & 70 & 23.8 & 0 & - \\
\hline Have you ever refused to care for a person with HIV/AIDS? & 71 & 24.1 & 223 & 75.9 & 0 & - \\
\hline
\end{tabular}


The results revealed that the majority of the respondents (79.1\%) was engaging in bad practices regarding HIV (see Figure 3).

\section{Factors associated with knowledge, attitudes and practices regarding HIV/AIDS}

From Table 6, it is clear that students who were aged 15-19 years were almost two times $(\mathrm{aOR}=1.72[1.41-2.11] ; p=0.00)$ more likely to have bad practice towards HIV/AIDS than those who were aged 20-24 years, while the Akans and those

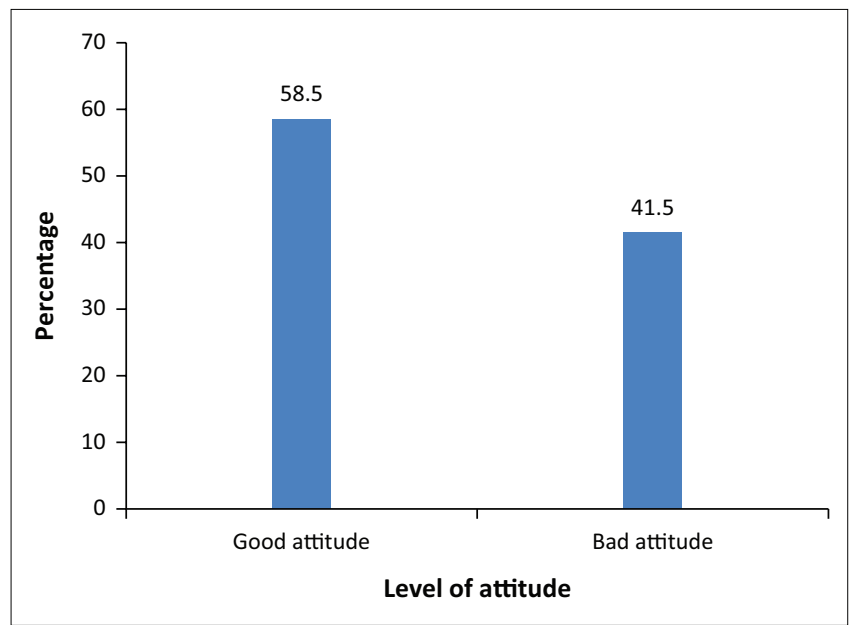

FIGURE 2: Level of attitude towards HIV/AIDS patients. who belong to other ethnic groups and those who were not married were all almost two times more likely to have bad practices regarding HIV/AIDS. On multivariate analysis, those students aged 15-19 years, Akans and singles were almost two times more likely to have bad practice.

Table 7 shows that students aged 15-19 years were four times $(\mathrm{OR}=4.36$; CI 3.24-5.86; $p=0.00)$ more likely to have a bad attitude towards HIV / AIDS than those who were aged 20-24 years, while the Fantes were almost three times more likely to have a bad attitude towards PLHIV than the Nzemas. On

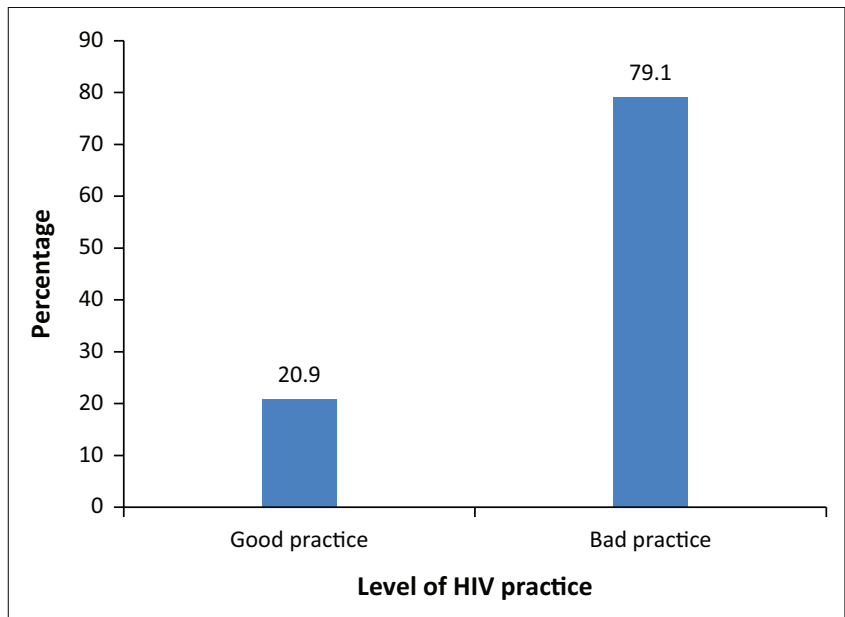

FIGURE 3: Level of practices regarding HIV.

TABLE 5: Comparison of levels of knowledge of HIV/AIDS among students aged 15-24 years by socio-demographic characteristics with $95 \%$ confidence.

\begin{tabular}{|c|c|c|c|c|c|c|c|c|}
\hline \multirow[t]{2}{*}{ Demographic variable } & \multicolumn{2}{|c|}{ Knowledge $($ Poor $=113$ ) } & \multirow[t]{2}{*}{ COR } & \multirow[t]{2}{*}{$95 \% \mathrm{Cl}$} & \multirow[t]{2}{*}{$p$} & \multirow[t]{2}{*}{ AOR } & \multirow[t]{2}{*}{$95 \% \mathrm{Cl}$} & \multirow[t]{2}{*}{$p$} \\
\hline & $n$ & $\%$ & & & & & & \\
\hline \multicolumn{9}{|l|}{ Age } \\
\hline $15-19$ years & 94 & 83.20 & 0.28 & $1.00-1.63$ & 0.23 & 0.2 & $0.74-0.92$ & 0.14 \\
\hline $20-24$ years & 19 & 16.80 & Ref. & - & - & Ref. & - & - \\
\hline \multicolumn{9}{|l|}{ Sex } \\
\hline Male & 50 & 44.30 & Ref. & - & - & Ref. & - & - \\
\hline Female & 63 & 55.70 & 1.13 & $0.92-1.38$ & 0.24 & 1.09 & $0.92-1.29$ & 0.32 \\
\hline \multicolumn{9}{|l|}{ Religion } \\
\hline Christian & 105 & 92.90 & Ref. & - & - & Ref. & - & - \\
\hline Islam & 7 & 6.20 & 1.6 & $1.23-2.06$ & 0.00 & 1.51 & $1.19-1.91$ & 0.00 \\
\hline African Indigenous & 1 & 0.90 & 0.81 & $0.62-1.06$ & 0.13 & 0.81 & $0.63-1.05$ & 0.11 \\
\hline \multicolumn{9}{|l|}{ Name of school } \\
\hline F SHS & 37 & 32.70 & 1.3 & $1.11-1.52$ & 0.01 & 1.93 & $1.71-2.18$ & 0.06 \\
\hline S College & 36 & 31.90 & Ref. & - & - & Ref. & - & - \\
\hline TSHS & 40 & 35.40 & 0.77 & $0.56-1.05$ & 0.10 & 0.46 & $0.35-0.62$ & 0.00 \\
\hline \multicolumn{9}{|l|}{ Ethnic group } \\
\hline Ahanta & 10 & 8.90 & 1.34 & $1.15-1.58$ & 0.00 & 2.84 & $2.55-3.18$ & 0.00 \\
\hline Nzema & 14 & 12.40 & Ref. & - & - & Ref. & - & - \\
\hline Fante & 34 & 30.10 & 1.74 & $1.36-2.22$ & 0.05 & 1.57 & $1.26-1.97$ & 0.03 \\
\hline Akan & 29 & 25.70 & 0.48 & $0.34-0.67$ & 0.00 & 0.38 & $0.28-0.50$ & 0.00 \\
\hline Ewe & 20 & 17.60 & 1.54 & $1.17-2.02$ & 0.02 & 1.24 & $0.98-1.57$ & 0.00 \\
\hline Other & 6 & 3.30 & 1.43 & $1.08-1.91$ & 0.01 & 1.14 & $0.89-1.47$ & 0.31 \\
\hline \multicolumn{9}{|l|}{ Marital status } \\
\hline Married & 0 & & Ref. & - & - & Ref. & - & - \\
\hline Single & 110 & 97.40 & 1.27 & $1.01-1.59$ & 0.04 & 1.45 & $1.30-1.63$ & 0.00 \\
\hline Dating & 3 & 2.60 & 1.07 & $0.78-1.45$ & 0.69 & 0.89 & $0.75-1.08$ & 0.25 \\
\hline \multicolumn{9}{|l|}{ Form } \\
\hline One & 43 & 38.10 & 0.75 & $0.49-1.15$ & 0.19 & 0.76 & $0.51-1.15$ & 0.20 \\
\hline Two & 70 & 61.90 & 0.51 & $0.33-0.77$ & 0.01 & 0.64 & $0.43-0.95$ & 0.03 \\
\hline
\end{tabular}

SHS, senior high school; Ref., reference class; COR, crude odds ratio; AOR, adjusted odds ratio; Cl, confidence interval. 
TABLE 6: Comparison of prevention practice regarding HIV/AIDS among students aged 15-24 years by socio-demographic characteristics with 95\% confidence.

\begin{tabular}{|c|c|c|c|c|c|c|c|c|}
\hline \multirow[t]{2}{*}{ Demographic variable } & \multicolumn{2}{|c|}{ Practice $(\mathrm{Bad}=53)$} & \multirow[t]{2}{*}{ COR } & \multirow[t]{2}{*}{$95 \% \mathrm{Cl}$} & \multirow[t]{2}{*}{$p$} & \multirow[t]{2}{*}{ AOR } & \multirow[t]{2}{*}{$95 \% \mathrm{Cl}$} & \multirow[t]{2}{*}{$p$} \\
\hline & $n$ & $\%$ & & & & & & \\
\hline \multicolumn{9}{|l|}{ Age } \\
\hline $15-19$ years & 41 & 77.4 & 2.03 & $1.59-2.61$ & 0.00 & 1.72 & $1.41-2.11$ & 0.08 \\
\hline $20-24$ years & 12 & 22.6 & Ref. & - & - & Ref. & - & - \\
\hline \multicolumn{9}{|l|}{ Sex } \\
\hline Male & 28 & 52.8 & Ref. & - & - & Ref. & - & - \\
\hline Female & 25 & 47.2 & 0.51 & $0.33-0.77$ & 0.00 & 0.64 & $0.43-0.95$ & 0.03 \\
\hline \multicolumn{9}{|l|}{ Religion } \\
\hline Christian & 51 & 96.2 & Ref. & - & - & Ref. & - & - \\
\hline Islam & 2 & 3.8 & 0.57 & $0.49-0.69$ & 0.04 & 0.75 & $0.65-0.85$ & 0.06 \\
\hline African Indigenous & 0 & 0.0 & 0.78 & $0.67-0.91$ & 0.00 & 0.89 & $0.77-1.02$ & 0.09 \\
\hline \multicolumn{9}{|l|}{ Ethnic group } \\
\hline Ahanta & 4 & 7.6 & 0.92 & $0.78-1.07$ & 0.28 & 1.23 & $1.07-1.42$ & 0.00 \\
\hline Nzema & 5 & 9.4 & Ref. & - & - & Ref. & - & - \\
\hline Akan & 19 & 35.8 & 1.74 & $1.36-2.22$ & 0.00 & 1.57 & $1.26-1.97$ & 0.00 \\
\hline Ewe & 6 & 11.3 & 0.48 & $0.34-0.67$ & 0.00 & 0.38 & $0.28-0.50$ & 0.00 \\
\hline Other & 1 & 1.9 & 1.54 & $1.17-2.02$ & 0.00 & 1.24 & $0.98-1.57$ & 0.07 \\
\hline \multicolumn{9}{|l|}{ Marital status } \\
\hline Married & 0 & 0.0 & Ref. & - & - & Ref. & - & - \\
\hline Single & 50 & 94.0 & 1.90 & $1.53-2.23$ & 0.00 & 1.79 & $1.44-2.23$ & 0.00 \\
\hline Dating & 3 & - & 1.16 & $0.90-1.49$ & 0.25 & 1.13 & $0.89-1.43$ & 0.31 \\
\hline \multicolumn{9}{|l|}{ Form } \\
\hline One & 16 & 30.0 & 1.11 & $0.85-1.45$ & 0.04 & 0.74 & $0.63-0.88$ & 0.06 \\
\hline Two & 37 & 70.0 & 1.17 & $0.92-1.47$ & 0.20 & 1.04 & $0.47-1.25$ & 0.68 \\
\hline
\end{tabular}

Ref., reference class; $\mathrm{COR}$, crude odds ratio; $\mathrm{AOR}$, adjusted odds ratio; $\mathrm{Cl}$, confidence interval; $p$, probability at $0.05 \%$; Form, level of secondary school.

TABLE 7: Socio-demographic correlates of students' attitude towards HIV/AIDS.

\begin{tabular}{|c|c|c|c|c|c|c|c|c|}
\hline \multirow[t]{3}{*}{ Demographic variables } & \multicolumn{8}{|c|}{ Attitudes } \\
\hline & \multicolumn{2}{|c|}{ Bad (53) } & \multicolumn{3}{|c|}{ COR } & \multicolumn{3}{|c|}{ AOR } \\
\hline & $n$ & $\%$ & $n$ & $95 \% \mathrm{Cl}$ & $p$ & $n$ & $95 \% \mathrm{Cl}$ & $p$ \\
\hline \multicolumn{9}{|l|}{ Age } \\
\hline $15-19$ years & 41 & 77.4 & 4.36 & $3.24-5.86$ & 0.000 & 3.2 & $2.58-3.96$ & 0.03 \\
\hline $20-24$ years & 12 & 22.6 & Ref. & - & - & Ref. & - & - \\
\hline \multicolumn{9}{|l|}{ Sex } \\
\hline Male & 28 & 52.8 & Ref. & & & Ref. & & \\
\hline Female & 25 & 47.2 & 0.51 & $0.33-0.77$ & 0.000 & 0.64 & $0.43-0.95$ & 0.03 \\
\hline \multicolumn{9}{|l|}{ Religion } \\
\hline Christian & 51 & 96.2 & Ref. & - & - & Ref. & - & - \\
\hline Islam & 2 & 3.8 & 0.57 & $0.42-0.77$ & 0.000 & 0.34 & $0.27-0.45$ & 0.00 \\
\hline African Indigenous & 0 & 0.0 & 1.49 & $1.08-2.06$ & 0.020 & 1.01 & $0.75-1.36$ & 0.95 \\
\hline \multicolumn{9}{|l|}{ Ethnic group } \\
\hline Nzema & 5 & 9.4 & Ref. & - & - & Ref. & - & - \\
\hline Fante & 18 & 34.0 & 2.72 & $1.92-3.85$ & 0.000 & 1.3 & $0.95-1.78$ & 0.10 \\
\hline Akan & 19 & 35.8 & 1.14 & $0.83-1.57$ & 0.410 & 0.62 & $0.47-0.82$ & 0.00 \\
\hline Ewe & 6 & 11.3 & 0.86 & $0.63-1.18$ & 0.358 & 0.38 & $0.29-0.50$ & 0.03 \\
\hline Other & 1 & 1.9 & 0.57 & $0.42-0.77$ & 0.000 & 0.34 & $0.27-0.45$ & 0.02 \\
\hline \multicolumn{9}{|l|}{ Marital status } \\
\hline Married & 0 & 0.000 & Ref. & - & - & Ref. & - & - \\
\hline Single & 50 & 94.3 & 1.93 & $1.53-2.43$ & 0.000 & 1.79 & $1.44-2.23$ & 0.00 \\
\hline Dating & 3 & 5.7 & 1.16 & $0.90-1.49$ & 0.250 & 1.13 & $0.89-1.43$ & 0.31 \\
\hline \multicolumn{9}{|l|}{ Form } \\
\hline One & 16 & 30.2 & 1.11 & $0.85-1.45$ & 0.460 & 0.74 & $0.63-0.88$ & 0.00 \\
\hline Two & 37 & 69.8 & 1.17 & $0.92-1.47$ & 0.200 & 1.04 & $0.87-1.23$ & 0.30 \\
\hline
\end{tabular}

Ref., reference class; COR, crude odds ratio; AOR, adjusted odds ratio; Cl, confidence interval; $p$, probability at $0.05 \%$; Form, level of secondary school. 
multivariate analysis, those students who were aged 15-19 years were three times more likely to have a bad attitude towards PLHIV than those aged 20-24 years (aOR = 3.20; CI 2.58-3.96; $p=0.03$ ).

\section{Discussion}

This study aimed at investigating KAPs regarding HIV/ AIDS among SHS students in Ghana. In our KAP study, we found students were more knowledgeable about modes of transmission in general. The attitudes of participants towards HIV and AIDS patients were mixed. More than three-quarters of participants were engaged in bad risk practices. However, few misconceptions were found among participants: $69.7 \%$ knew that HIV cannot be transmitted by sharing clothes with an HIV-infected person, and $60.5 \%$ knew that HIV cannot be transmitted by using the same toilet seat as an HIV-positive person. Notably, only 174 (59.2\%) knew that HIV/AIDS is not curable. Factors associated with poor knowledge of HIV/ AIDS (Muslim religion, attending F and T SHSs ( $\mathrm{F}$ and $\mathrm{T}$ senior high schools), belonging to the Ahanta ethnic group and being single), bad attitude towards HIV/AIDS (being aged between 15 and 19 years, being single and belonging to the Fante ethnic group) and bad practices (age between 15 and 19 years, belonging to the Akan ethnic group and being single) were also determined.

The current results indicated that the majority of the respondents knew that HIV could be transmitted by sexual intercourse, from mother to child, by sharing contaminated needles or syringes and through blood transfusion. These findings are in agreement with two Ghanaian studies. ${ }^{10,26}$ Agyemang et al. ${ }^{10}$ conducted a cross-sectional study among high school students in the Ejura-Sekyedumase district of Ghana and found that sexual intercourse was the most commonly identified means of HIV transmission (95.0\%), followed by sharing of razors, needles or other sharp items with an infected person $(86.0 \%)$ and blood transfusion $(37.1 \%) .{ }^{10}$ Furthermore, Agyekum and Suapim, ${ }^{26}$ in a crosssectional study among high school girls in Ghana, revealed that almost all the respondents $(90.0 \%)$ were aware that HIV/ AIDS could be transmitted through bodily fluids like blood, semen, vaginal secretions and breast milk. ${ }^{26}$ Exposure to several awareness campaigns partially can explain these results; however, our study showed an adjusted association between knowledge of HIV and Muslim religion, attending an FSHS, belonging to the Ahanta ethnic group and being single. This association with the lower age group is similar to what has been seen in Ghana, where only one out of two adolescents has a comprehensive knowledge of HIV. ${ }^{19}$ The low self-efficacy measures and the difficult access to protective measures such as condoms among youths owing to resistance and shame from selling points could as well explain this association.

Single marital status is associated with the odds of little knowledge and odds of getting infected, as demonstrated by Carlos in Congo, where being single, divorced or widowed increases the likelihood of getting infected almost ten times. ${ }^{27}$
The big difference in the odds of infection in single participants in Congo compared to ours could be explained by specific characteristics of participants. While our study was focussed on school-going youth, the Congolese study's participants were a mix of youths and adults, with a median age of 34.9 years. ${ }^{27}$

There is a direct relation between sexual behaviour and misconceptions in HIV knowledge. ${ }^{28}$ Most of the respondents in the current study knew that HIV/AIDS cannot be transmitted through handshake $(81.3 \%)$, by wearing the clothes of an HIV-infected person (69.7\%), by mosquito bite $(70.1 \%)$, through witchcraft $(73.8 \%)$ or by using the same toilet seat as an HIV-positive person (60.5\%). These findings contravene those of Christane et al., ${ }^{19}$ who reported in their study conducted in Libreville, Gabon, using a cross-sectional survey, that nearly half of their respondents incorrectly thought that HIV could be transmitted by eating from the same plate, drinking from the same glass, wearing the same clothes and sharing a toilet with a PLHIV. ${ }^{19}$ These differences might have been a result of increased level of HIV education programmes rolled-out in the Sekondi-Takoradi metropolis compared to that in Libreville, Gabon. However, the finding regarding mosquitoes transmitting HIV agrees with theirs as $67.7 \%$ of their respondents correctly answered that mosquitoes do not transmit HIV compared to $70.1 \%$ in the current study. These findings also supported Tarkang, who conducted a quantitative, non-experimental, descriptive, explorative and correlational research in Kumba, Cameroon, and reported that respondents showed some misconception that HIV/AIDS can be transmitted through mosquito bite (38.4\%), through toilet seats $(21.8 \%)$ and through handshake with an infected person (5.3\%) as compared to $19.5 \%, 23.5 \%$ and $13.3 \%$, respectively, in this study. ${ }^{29}$ These similarities could be attributed to some degree of misconception that many people still have regarding HIV transmission across Ghana and even Africa. Just more than $40 \%$ of the respondents in the current study had the misconception that HIV is curable. The factors associated with these misconceptions in our study are taking care for a relative with HIV and sharing the same plate with an AIDS patient, which increases the risk by 2 and 3 times, respectively. These factors were explored in a Congolese study as well which showed an association between misconceptions and risk of transmission such as HIV can be transmitted by sorcery and by mosquito bite. ${ }^{27}$ The implication of this kind of misconception is that these respondents would indulge in practices that might decrease the support system for the patient in an incurable chronic disease where a strong social support system plays a critical role in the resilience of the patient or the HIV-positive individual. This will definitely impact on the overall management and the outcomes thereof. There is therefore a need to implement health promotion programmes among students in the study area in order to improve their knowledge level regarding HIV/AIDS. The same study conducted in Kinshasa, Congo (Democratic Republic of Congo [DRC]), reported more than three of these misconceptions 
(the thinking that an HIV-positive person cannot look healthy and that HIV is transmitted by sorcery; it is God's punishment; and it spreads through a kiss on the mouth, mosquitoes, coughs/sneezes or undercooked food) were associated with HIV. ${ }^{27}$ However, even if these associations of misconceptions on HIV status were found in both the studies, our study uses a slightly different questionnaire to detect misconceptions, which limits the comparison between the two studies. Nonetheless, in the multivariable analysis, three misconceptions have shown an association with knowledge of transmission modes (HIV can be transmitted by wearing HIV-positive patient's clothes, by handshake or by mosquito bite). Furthermore, like in the Congolese study, ${ }^{27}$ an association between misconceptions and socio-demographic variables was not established in our study. This decreases somewhat the ability of our results in designing interventions tailored to participants aimed at reducing the impact of those misconceptions on their HIV risk.

Overall, the knowledge level of respondents of HIV/AIDS was found to be encouraging as the majority $(61.6 \%)$ had good knowledge regarding HIV / AIDS. This finding contradicts that of Agyemang et al., ${ }^{10}$ who revealed in their study in the EjuraSekyedumase district of Ghana that $33.6 \%$ of their study respondents had good knowledge regarding HIV/AIDS, and that of Huda and Amanullah,, ${ }^{12}$ who carried out a crosssectional study in Bangladesh and demonstrated that $34.4 \%$ of the students had good knowledge regarding HIV / AIDS. ${ }^{12}$ The significant level of knowledge of respondents in this study testifies to the positive impact of the HIV educational programmes organised in the Sekondi-Takoradi Municipality by the Ghana AIDS Commission and other organisations over the years. However, knowledge regarding HIV/AIDS should be universal. Therefore, the accurate knowledge level of $61.6 \%$ reported in the current study should be considered inadequate. This calls for concerted efforts and health promotion programmes among SHS students in Secondi-Takoradi, to increase their level of knowledge regarding HIV/AIDS to $100 \%$. Inaccurate knowledge might lead to negative attitudes towards PLHIV, which could in turn lead to stigma and discrimination.

Attitudes of respondents towards PLHIV showed that the majority $(79.3 \%)$ of them was willing to care for their relatives with HIV/AIDS. However, $57.5 \%$ of them said they would not eat from the same bowl used by a PLHIV. A number of participants believed that they cannot share a cup with a PLHIV or buy from an HIV-positive shopkeeper, while more than three-quarters saw no harm in allowing teachers and students to continue with their jobs or studies while living with HIV.

These attitudes, despite being ambiguous on some points, are similar to the findings of Nubed and Akoachere, ${ }^{1}$ namely that $52.5 \%$ of students had positive attitudes towards PLHIV and $47.5 \%$ had negative attitudes, compared to $58.5 \%$ and $41.5 \%$ of this study, respectively.
Their cross-sectional study in Fako Division, Cameroon, revealed that $52.6 \%$ of respondents indicated their willingness to take care of a sick HIV-positive relative or continue friendship with an HIV-positive friend, while 56.9\% could buy food and other goods from an HIV-positive person. Their study further revealed that the majority of the participants accepted that an HIV-positive student should be allowed to continue her/his studies (71.6\%) and that an HIV-positive teacher should be allowed to continue her/his teaching profession $(75.0 \%) .{ }^{1}$ The current findings differed from a cross-sectional study by Christane et al., ${ }^{19}$ which found that less than half of the respondents showed positive attitudes on issues such as buying items from an HIV-positive shopkeeper or food seller, allowing an HIV-positive student to continue her/his studying in school and allowing an HIVpositive teacher to continue her/his teaching in school. However, the positive attitude among $58.5 \%$ of the respondents in the current study agrees with theirs as they reported in their study that $55.7 \%$ of their respondents manifested a positive attitude towards PLHIV. The current findings imply that the study respondents had some level of acceptance of HIV-positive persons into society in the Sekondi-Takoradi metropolis. It also means being HIVpositive is not an end to one's career or profession.

However, the positive attitude among $58.5 \%$ of participants towards PLHIV reported in the current study falls short of the zero-discrimination against PLHIV as prescribed by UNAIDS. $^{30}$ This could be because of the low level of knowledge regarding HIV/AIDS among the study respondents $(61.6 \%)$. The $41.5 \%$ of respondents with negative attitudes may manifest some level of discrimination against PLHIV. Therefore, many health promotion activities and interventions are still needed in the Secondi-Takoradi metropolis to improve students' attitudes towards PLHIV.

It was found in the current study that $26.2 \%$ of the respondents had a history of sexual intercourse, with $51.9 \%$ using a condom during the first sexual intercourse and $41.5 \%$ regularly using it. More than half (56.1\%) of the sexually active respondents had multiple sex partners in the previous year. Some of the respondents $(6.4 \%)$ were found to have used or were using injection drug equipment. These results differ from those of a cross-sectional study by Christane et al. ${ }^{19}$ in Libreville, Gabon, which reported that $73.0 \%$ of school students had a history of sexual intercourse, $29.6 \%$ were using condoms during sex and $25.6 \%$ used condoms regularly during sexual intercourse with casual partners. ${ }^{19}$ The current results also show that more students used condoms than reported by Adeleke et al. ${ }^{5}$ in their cross-sectional study conducted among school-going adolescents in Atisbo Local Government Area, Nigeria (20.4\%). This is a cause for great concern in a population where several combined risk factors are found, but the use of condoms is still low and even inconsistent. Indeed, half of our study population did not use a condom both during their first sexual intercourse and during their last sexual encounter; however, slightly more than half of them had multiple sex partners at the time. An education on condom use is warranted. 
On the other hand, a cross-sectional survey conducted among male high school students in Lao People's Democratic Republic reported a higher figure of $31.3 \%$ of students having a history of sexual intercourse, and $70.2 \%$ of these had used a condom, compared to the current result of $20.8 \%$ and $47.4 \%$, respectively. ${ }^{31}$ These discrepancies could be a result of their study involving only males, who mostly engage in risky life behaviours, as compared with the current study, which included both males and females. Here, we found inconsistent condom use; only half of the respondents used condoms during their sexual encounters, while close to $50 \%$ had unprotected sexual intercourse. This shows the discordance between the high risks of contracting HIV among these youths consistent with studies carried out elsewhere. ${ }^{32}$

There was association of KAPs with some socio-demographic characteristics, unlike in a study conducted in the EjuraSekyedumase district of Ghana, in which no association was found between the demographic characteristics and knowledge of HIV/AIDS. ${ }^{10}$ In our case, respondents aged 15-19 years, single, belonging to the Muslim religion and studying at school $\mathrm{F}$ were associated with poor knowledge on HIV/AIDS. In Congo, the DRC Demographic Health Survey has shown a relationship between ages 15 and 24 years and being unable to know that healthy people can be HIV-positive. ${ }^{33}$ The low level of knowledge associated with being Muslim in the current study calls for a collaborative effort between health authorities and religious leaders to address some misbeliefs among the general public. The same age range and the single marital status also were associated significantly with a poor attitude towards HIV/ AIDS and HIV-positive people. This poor attitude can increase the rejection of AIDS patients and compromise the fight against HIV, such as use of condoms among youth, among others.

\section{Limitations}

This study was restricted to only three schools in the western region of Ghana and all the participating institutions were boarding schools excluding form (grade level) three. This limits the generalisability of the current findings to other regions and today's SHSs. The study only concentrated on knowledge as the primary factor in explaining HIV transmission among young people, which may not be so. The study failed to explore relevant points related to sexual behaviour in youths, such as some attitudes surrounding condom use, the age of sexual debut and high personal HIV risk perception. Lack of such information may impede the design of a culturally tailored message to this group able to reverse their possible bad risk behaviour. Finally, because the questionnaire was self-administered, social desirability bias may have occurred. However, the anonymity of the respondents hopefully encouraged students to be honest in their responses. Despite all of these limitations, the researchers believe that this study might be a reasonable source of information for other researchers and policymakers.

\section{Recommendations}

Based on the findings of this study, the following suggestions can be formulated:

- Human immunodeficiency virus/acquired immunodeficiency syndrome awareness campaigns among SHS students in the metropolis should generally pay much attention to specific issues, especially regarding the transmission and management of HIV / AIDS.

- Sexuality education in schools should be reinforced to correct the misconceptions observed in the current study and encourage safe practices and positive attitudes towards PLHIV.

- Furthermore, HIV/AIDS prevention programmes must move beyond education into encouraging and enhancing voluntary counselling and testing services among students.

- Human immunodeficiency virus/acquired immunodeficiency syndrome awareness and prevention campaigns must also be targeted at young people, especially those below 20 years of age, to help improve their attitudes towards PLHIV.

Future research involving regional and national representative samples of school-attending and out-of-school adolescents could contribute substantially to HIV / AIDS prevention.

\section{Conclusion}

The study revealed that SHS students in the three schools in which the study was conducted generally had some knowledge of the basics of HIV/AIDS, though it can be considered inadequate. However, there are still some gaps regarding the modes of transmission, such as transmission of HIV through handshake, sharing of clothes with an HIVpositive person, mosquito bite, witchcraft, etc., which need further attention. Furthermore, the knowledge and awareness on HIV/AIDS-related information did not translate to students' decision to undergo voluntary testing, with more than four-fifths of the students not knowing their HIV status. The attitudes of respondents towards PLHIV were found to be encouraging as a slight majority had a good attitude. The majority of the respondents engaged in risky practices regarding HIV. There was no significant association between KAPs regarding HIV / AIDS and socio-demographic variables except between age and attitudes.

\section{Acknowledgements Competing interests}

The authors declare that they have no financial or personal relationships that may have inappropriately influenced them in writing this article.

\section{Authors' contributions}

S.M.D. and E.E.T. conceived and designed the study, and analysed the data; E.E.T. led the writing of the manuscript; and P.M.L. critically reviewed the manuscript. All authors read and approved the final manuscript. 


\section{References}

1. Nubed CK, Akoachere J-FTK. Knowledge, attitudes and practices regarding HIV/ AIDS among senior secondary school students in Fako Division, South West Region, Cameroon. BMC Public Health. 2016;16(1):847. https://doi.org/10.1186/ s12889-016-3516-9

2. World Health Organization. HIV/AIDS fact sheet [homepage on the Internet] c2017 [cited 2018 Oct 2018]. Available from: http://www.unaids.org/sites/ default/files/media_asset/UNAIDS_FactSheet_en.pdf

3. UNAIDS. UNAIDS data [homepage on the Internet]. c2018 [cited 2018 Oct 13] Available from: http://www.unaids.org/sites/default/files/media_asset/unaidsdata-2018_en.pdf

4. Kharsany ABM, Karim QA. HIV infection and AIDS in sub-Saharan Africa: Current status, challenges and opportunities. Open AIDS J. 2016;10(1):34-48. https://doi. org/10.2174/1874613601610010034

5. Adeleke IT, Azeez BA, Aliyu D, Ogundiran LM, Salami A, Adeoye WA. HIV/AIDS awareness among secondary schools' adolescents in south-western Nigeria : A correlate to strengthen advocacy and strategic sexuality education programs. AJHR. 2015;3(1-1):61-67. https://doi.org/10.11648/j.ajhr.s.2015030101.19

6. Ghana AIDS Commission. 2014 Status report. Accra: Ghana AIDS Commission; 2014.

7. Ghana Statistical Service. Ghana: Demographic and health survey 2014 [homepage on the Internet]. Rockville, MD ICF International; 2015 [cited 2018 Oct 13]. on the Internet]. Rockville, MD ICF International; 2015 [cited 201
Available from: https://dhsprogram.com/pubs/pdf/fr307/fr307.pdf

8. Ghana AIDS Commission. Ghana country AIDS progress report (January 2010-December 2011). Accra: Ghana AIDS Commission; 2012.

9. Ghana AIDS Commission. Summary of the 2016 HIV sentinel survey report [homepage on the Internet]. c2016 [cited 2017 Nov 10]. Available from: http:// www.ghanaids.gov.gh/gac1/aids_info.php

10. Agyemang S, Buor D, Tagoe-Darko E. The extent of knowledge about HIV/AIDS among young people in the Ejura-Sekyedumase district of Ghana. J AIDS HIV Res. 2012;4(11):241-247. https://doi.org/10.5897/JAHR12.023

11. Masoda M, Govender I. Knowledge and attitudes about and practices of condom use for reducing HIV infection among Goma University students in the Democratic Republic of Congo. S Afr J Epidemiol Infect. 2013;28(1):61-68. https://doi.org/10. 1080/10158782.2013.11441521

12. Huda MN, Amanullah DA. HIV/AIDS-related knowledge among secondary schoo students in Bangladesh: A cross-sectional study. Adv Infect Dis [serial online] 2013 [cited 2018 Oct 2018];3:274-280. Available from: https://doi.org/10.4236/ aid.2013.34042

13. Doku D. Substance use and risky sexual behaviours among sexually experienced Ghanaian youth. BMC Public Health. 2012 Jul 29;12(1):571. https://doi. org/10.1186/1471-2458-12-571

14. Masood MSA, Alsonini NAA. Knowledge and attitude about reproductive health and family planning among young adults in Yemen. Int J Popul Res [serial online] 2017 [cited 2018 Jul 04]. Available from: https://www.hindawi.com/journals/ ijpr/2017/1895472/

15. Chen PF. HIV/AIDS prevention among young people in East and South-East Asia in the context of reproductive and sexual health. Asia Paci Popul. 2008;23(1):7.

16. CDC - Division of HIV/AIDS Prevention. HIV among women. Atlanta, GA: Centers for Disease Control and Prevention (CDC); 2013.
17. Gudi SK. Assessment of knowledge, attitude and perceptions of HIV/AIDS among secondary school students in Guntur district of south India: A cross-sectional secondary school students in Guntur district of south India: A cross-sectional survey. Int J Sci Rep.
IntJSciRep20181392

18. Aomreore AA, Alikor EA, Nkanginieme KE. Survey of knowledge of HIV infection among senior secondary school 3 (SSS3) students in Port Harcourt. Niger J Med. 2004;13(4):398-404.

19. Christane NA, Zamba MR, Masika J, Zhang Y, Zhang L. HIV/AIDS prevalence, knowledge, attitudes and related behaviors among young people in Libreville, Gabon. IOSR J Humanit Soc Sci. 2014;19(1):59-65. https://doi.org/10.9790/083719125965

20. Kumar P, Pore P, Patil U. HIV/AIDS-related KAP among high-school students of municipal corporation school in Pune. An interventional study. Natl J Community Med. 2012;3(1):74-79.

21. Mansoor AB, Fungladda W, Kaewkungwal J, Wongwit W. Gender differences in KAP related to HIV/AIDS among freshmen in Afghan universities. Southeast Asian J Trop Med Public Health. 2008;39(3):404-418.

22. Stephens LL, Bachhuber MA, Seloilwe E, Gungqisa N. HIV-related knowledge, attitudes, and practice among educated young adults in Botswana. J AIDS HIV Res. 2012;4(6):159-164.

23. Shuttleworth M. Cross sectional study - A snapshot of a population [homepage on the Internet]. 2010 [cited 2017 Nov 08]. Available from: https://explorable.com/ cross-sectional-study

24. Cochran WG. Sampling techniques. 3rd ed. New York: John Wiley; 1977; pp. 10-20.

25. UNICEF. Statistics at a glance: Ghana [homepage on the Internet]. 2013 [cited 2017 Feb 27]. Available from: https://www.unicef.org/infobycountry/ghana_statistics.html

26. Appiah-Agyekum NN, Suapim RH. Knowledge and awareness of HIV/AIDS among high school girls in Ghana. HIV AIDS (Auckl). 2013;5:137-144. https://doi. org/10.2147/HIV.S44735

27. Carlos S, Martínez-González MA, Burgueño E, et al. Misconceptions about HIV infection in Kinshasa (Democratic Republic of Congo): A case-control study on knowledge, attitudes and practices. Sex Transm Infect. 2014;0:1-4. https://doi. org/10.1136/sextrans -2014-051734

28. Tenkorang EY. Myths and misconceptions about HIV transmission in Ghana: What are the drivers? Cult Health Sex. 2013;15:296-310. https://doi.org/10.1080/1369 1058.2012.752107

29. Tarkang EE. Knowledge, attitudes and perceptions regarding HIV/AIDS and sexual behaviours among senior secondary school learners in Kumba, Cameroon [unpublished PhD thesis]. Pretoria: University of South Africa; 2009.

30. UNAIDS. Zero Discrimination Day to be celebrated around the world [homepage on the Internet]. c2015 [cited 2018 Oct 13]. Available from: http://www.unaids. org/sites/default/files/20150226_PR_Zero_Discrimination_Day_en.pdf

31. Thanavanh B, Harun-Or-Rashid M, Kasuya $H$, Sakamoto J. Knowledge, attitudes and practices regarding HIV/AIDS among male high school students in Lao People's Democratic Republic. J Int AIDS Soc. 2013;16:17387. https://doi.org/10.7448/ IAS.16.1.17387

32. UNAIDS. Report on the Global AIDS epidemic [homepage on the Internet]. c2013 [cited 2018 Oct 13]. Available from: http://files.unaids.org/en/media/unaids/contentassets/ documents/epidemiology/2013/gr2013/UNAIDS_Global_Report_2013 en.pdf

33. Ministère du Plan et Suivi de la Mise en œuvre de la Révolution de la Modernité (MPSMRM), Ministère de la Santé Publique (MSP), ICF International. [Demographic and health survey in Democratic Republic of the Congo 2013-2014]. Rockville, MD: MPSMRM, MSP, ICF International, 2014; French. 